Historic, Archive Document

Do not assume content reflects current scientific knowledge, policies, or practices. 



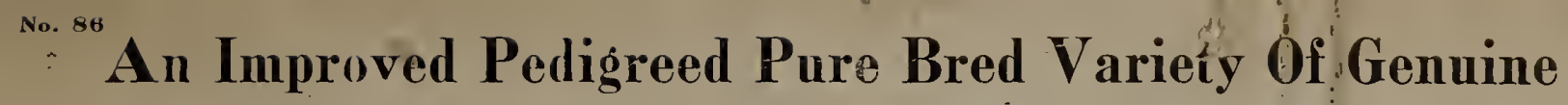
Texas Red Rust Proof Oats

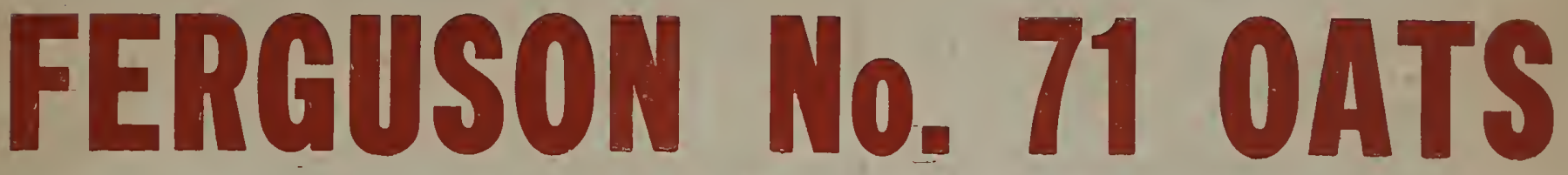

Sold Only With Our Seals And Certificates On Every Bag

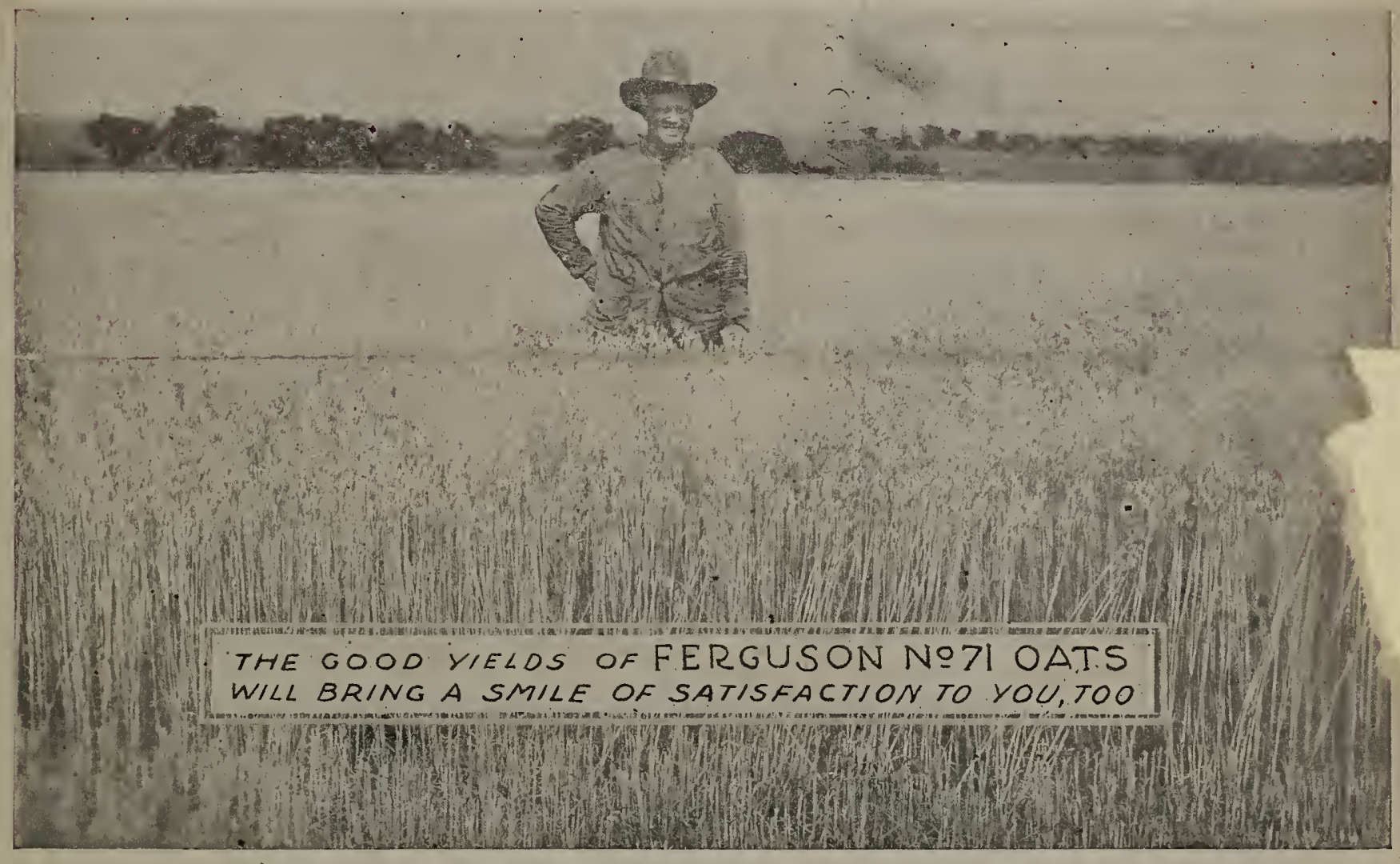

$\therefore$ Some Proven Advantages $\therefore$

Developed by 19 Years of Pedigreed Breeding

1. LARGER YIELD THAN COMMON RED OATS-More bushels and dollars per acre without extra labor-

2. A BFITER QUALITY OF GRAIN-Threshermen and grain dealers say so.

3. GREATER HARDINESS AGAINST WINTER KILLING_Affording more winter grazing and earlier maturity to escape spring drouths.

4. GREATER DROUTH RESISTANCE - Their superior yield in dry season has repeatedly proven this.

5. FREER STOOLING HABITS-Due to greater vigor, thus requiring less seed to sow.

6. GREA IER STIFF NESS OF' STKAW-Thus avoiding losses from iodging and blowing down.

7. MORE RESISTANCE TO RED AND BLACK RUST-Many customers have found that this has saved them from losses amounting to many dollars for every acre planted.

8. PRACTICAL FREEDOM FROM SMUT_Due to seed treatment given our seed every year. This in itself will save you more than the entire cost of your seed.

98 Per Cent of Our Customers Say Our Seed Have These Advantages: That They Gut the Meney for Each Quality, (Seo Pase Four)... It Was Money to Them... It Will Be Money to You.

Can You Afford to Lose by Continuing to Plant Common Thresher-run, Unimproved Seed,

When Improved, Pedigreed, R e c l e a n e d, Graded and Smut Treated Seed Can Be Had?

\section{FERGUSON SEED FARMS}

Breeders and Growers of Staple Seed For the Southwest

Sherman,

Texas

Distributing and Growing Stations at Howe, Texas, and Oklahoma City, Oklahoma 


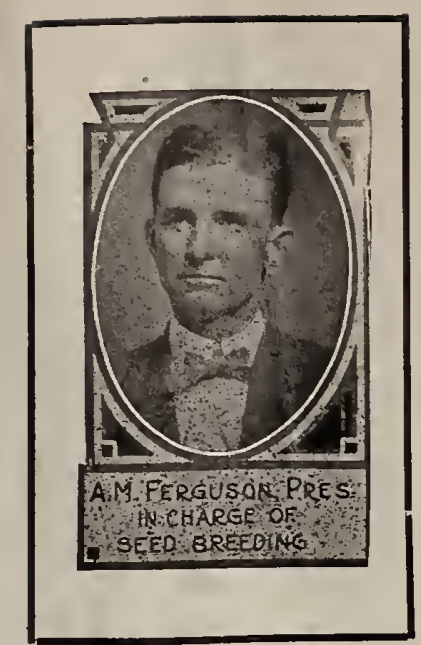

\section{The History of Ferǵuson No. 71 Oats \\ An Improved Pure-Bred Pedigreed Variety of Texas Red linst l'orof (Oals Developed by 19 Years of Breeding}

It is not Ferguson, but Ferguson's 19 years of persistent, rigid practice of applying approved scientific METHODS of pedigreed Seed Breeding that explains why his seeds have habitually proven to be "better yielders" than "just selected seeds."

\section{Y entrs of Breeding-10 Years Proven Success}

Ferguson No. 71 Oats have been on the market only 10 years, but they are the result of 19 years of systematic effort on the part of Mr. Ferguson to improve the native Southern Red Oat-to produce an improved strain of this oat that would possess Larger Yielding Qualities, Greater Rust Resistance, Freer Stooling Habits and Greater Hardiness Against Cold.

Mr. Ferguson began his work with oats 19 years ago. More than 500 individual selections were tested in his breeding grounds. Rigid selection was practiced and many valuable strains were discovered. His final selection-the best-by-test of all these-happened to be "Number 371" and was named FERGUSON NO. 71 OAT.

Working with several thousand selections for 19 years, he has assured himself by careful and systematic tests of the advantages of the good qualities possessed by FERGUSON NO. 71 OATS. We can offer no stronger proof that this pedigreed strain does possess advantages over ordinary oats than the letters we have received from growers of this oat, a number of which we reproduce, telling in their own words the advantages they recognized after growing these oats.

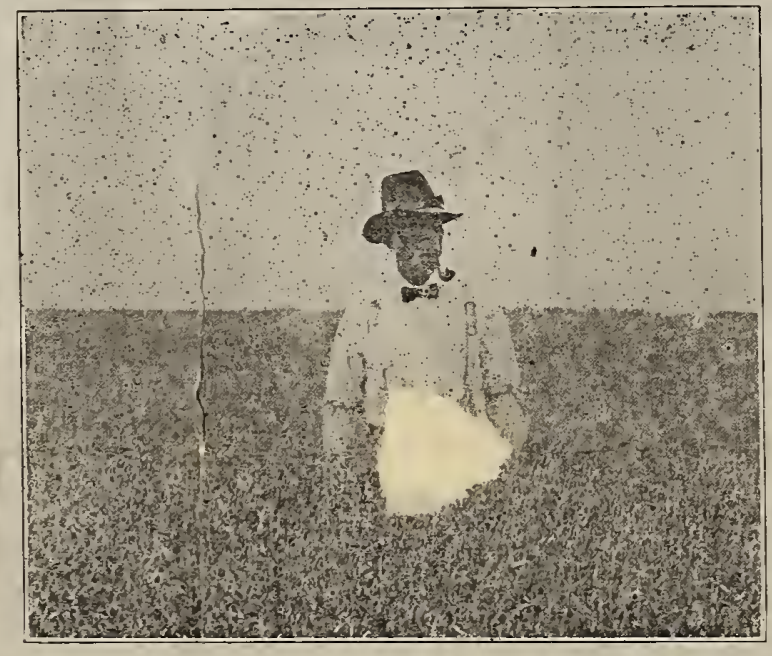

FERGUSON NO. 71 OATS

Mre. Armstron
OUIR MIROMISIIS $\therefore$ AND Here is what we promised.

ere is what our customers reported (Read a few letters for the proof)
Crops Uniform in Straw and Grain. Five to Forty Bushels Increase in Yield. Unexpected Yields From Low, Stout Stems.

Absolute Freedom or Slight Losses From Red and Black Rust.

Little or no Losses from Blasted Heads.

That they Stood the Winter Better than Common Oats.

That the Crop did not Lodge even on Strong Land.

That Less Seed was required Per Acre

Tests Showed Grain to be Heavier than the Native Oats.

Made Extra Money by Selling Their Crops for Seed to Their Neighbors.

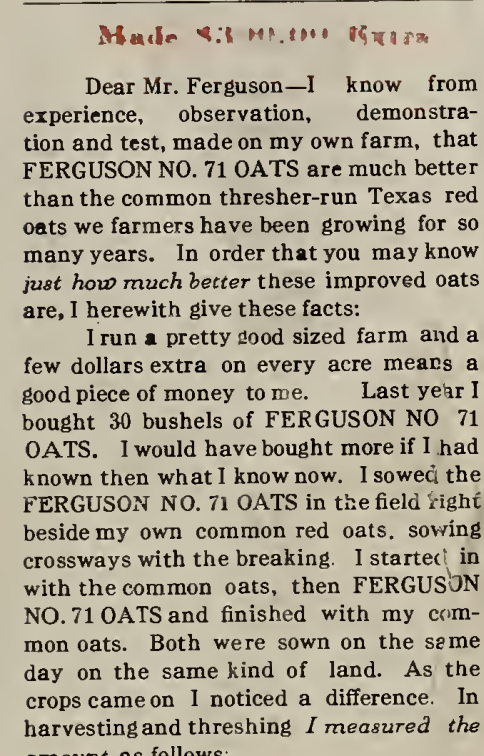
harvesting and threshing $I$ measured the

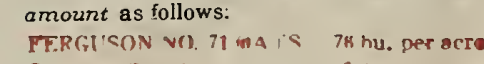
ver acre

\section{Lost Two Thousand Dollars}

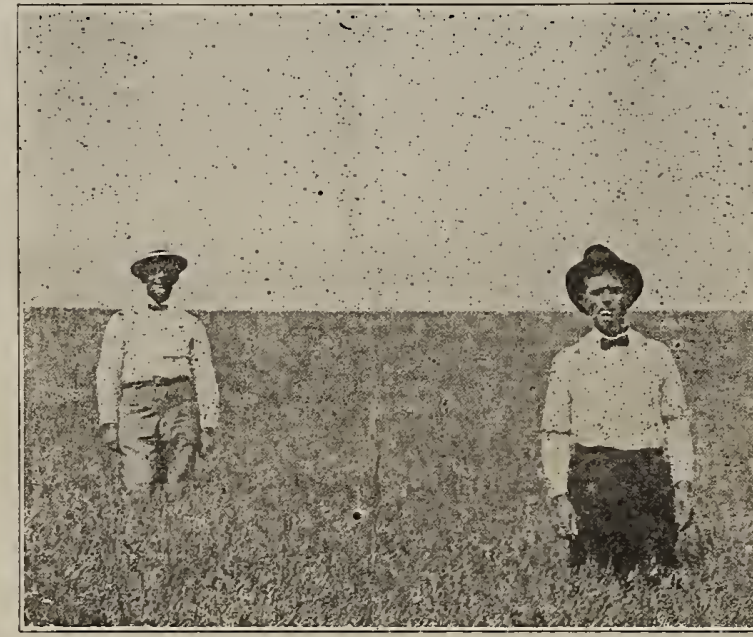

Prices and Gu: rantee

If you are going to plant $\theta$ ats, why not make sure of a good crop by planting extra clean, sound, heavy seed of a proven high
yielding variety? Count yielding variety? Count up the advantages as noted in the letters of growers who have tested all varieties. Early fall seed-

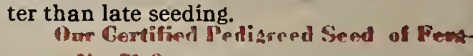
moon No 31 Cats are doubly recleaned and graded, and then treated for smut in our special seed oat grading plant, the most complete in the South.

They are put up in heavy, new, branded 150-lb. bags with our Seal and Certificateof Good Breeding on every bag, and sold F. O. B. our station, on our

\section{STRINGLESS GUARANTEE}

as Cur int prices are given in Current prices are given in the latest
issues of FERGUSON'S SEED CURRENT, issues of FERGUSON'S SEED CURRENT, a monthly price current on all kinds of Seeds
for Fields, Gardens and Lawns. Free on ror Fields

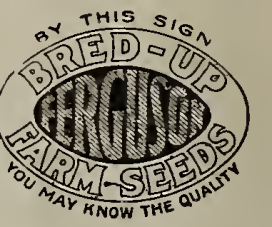

\section{How Our Customers Make and Save}

By Producing Large Yields From Bred- $I^{\prime} p$ Seeds. Our customers report increas-

ed yields varying frox 5 to 45 bushels pær acre more than their native oats. This means from $\$ 4$ to $\$ 45$ per acre EXTRA PROFIT due to the use of FERGUSON NO. 71 OATS, even when sold as just feed oats.

By Planting Sinut-Free Treated Seeds. W'e treat not only our uwn stuck seed to prevent smut in the crop, but also every bushel of oats we ship out. This means that the crup will be practically free from smut for two or more years. Our smut-free seeds will be worth the price to you regardless of other advantages. This gain is usually 3 per cent to 20 per cent, amounting to 3 to 12 bushels per acre.

By Raising A Rust-Proof Oat. Red and black rust are common causes of low yield in oats. Nearly every customer reports little or no rust in FERGU ON NO. 71 OATS. Mr. M. C. Abrams says his crop had "no rust at all;others had some."

By Using A Drouth-Resisting Oat. In dry seasons FERGUSON NO. 71 OAT with its deep-rooted, free-stooling habits and small but stiff straw, produces a more profitable and satisfactory crop than the ordinary red oats, wherever they have been tried out by growing side by side, especially in the Southwest.

By Reducing Losses From Winter Killing. FERGUSON NO. 71 OATS are distinctly hardier and more resistant to winter killing by cold than the common red oats, as proven in our many tests, (we are near the northern limit of fall planted red oats) and the many cases where our customers report FERGUSON NO. 71 OATS going through the winter with good crops when others, under the same ccnditions, were completely frozen out. Have stuod near zero freezes.

By. Using Heavy Recleaned Graded Seed. Quick growing seeds reduce losses by producing healthy plants and avoiding poor stands. Our certified seed of FERGUSON NO. 71 OATS are carefully treated and doubly recleaned, and graded by power driven machinery especially desisi:ed fur preparing seed odts: 1hey are $98 \%$ to $99 \%$ sound, heavy, plimp
By Producins A More Valuable Oat. Threshermen and grain dealers advise drowers of FERGUSON NO. 71 OATS not to sell their crups on the general market but sell to their fellow farmers for seed. Many of our customers advise us, when ordering freshly improved stuck, that they are selling a part of their crop to their neighbors for seed at a good premium over the market. Read their statements. The frequency of these reports is good evidence that FERGUSON NO. 71 OATS are a valuable crop for the extra-price-per-bushel, to say nothing of the extra bushels. Your neighbors will be convinced by seeing the crops. Every Claim We Make Is Verified By Former Customers. See their letters herein. Hundreds more on request. Ten years of proven success is the record. We sell only our own freshly improved pedigreed seed in sealed bags.

By Using Less Seed. FERGUSON NO. 71 OATS are free-stooling and require less seed to the acre than ordinary oats; 1 to $1 \frac{1 / 2}{2}$ bushels will produce a better stand than double the amount of ordinary oats. The cost "per bushel" of FERGUSON NO. 71 OATS is slightly more, but the cost "per acre" is usually less. Mr. T. J. Welch planted 10 bushels of FERGU. SON NO. 71 OATS on 10 acres and harvested 715 bushels. Read his letter below:

Large Yield From One Bushel Per Acre, "I sowed them the middle of February and threshed $71 \frac{1}{2}$ bushels per acre, or 715 bushels for the 10 bushels I bought and sowed. I sold the crop for seed. The following order will show how well pleased I am: Enclosed find check for 55 bushels of your FERGUSON NO. 71 OATS. Success to you in the oat business."-T. J. Welch, Brown County, Texas.

No, 71. Oats Mare 84 $\frac{1 / 2}{2}$ Bushels; Common Oats 40. "FERGUSON NO. 71 OATS are the best on the market and I will plant nothin 3 else, as I lost at least $\$ 31.50$ per acre by not planting all my crop in FERGUSON NO. 71 OATS, counting oats at 70 cents per bushel. The quality was extra good and they stuoled freely. My common oats made 40 bushels and the FERGUSON NO. 71 OATS under the same conditions made $84 \frac{1}{2}$ bushels per acre. Yours for better odts."-J. G. Wilkerson, Grandview, Texas, Route No. 4.

Your Labor and Land Will Do As Well If You Plant Ferguson No. 71 Oats 


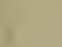


Sold Only With Our Seals and Certificates on Every Bag.

Mode 25 Bu. More; Sold at Premium of 8 Cents. "I am well pleased with the results from my crop of FERGÚSON NO. 71 OATS, as I made about 25 bushels more per acre and sold my crop for $65 \mathrm{c}$ per bushel when other oats werre bringing only $57 \mathrm{c}$. Your oats are bringing me \$21 an acre more than the common oats. I recommend them to anyone looking for bigger yields and more money." - E. H. Bootright, Muskogee County, Oklahoma,

80 - Bushels vs. 40 Bushels. "The oats are all right. They turned out well. They threshed 80 bushels per acre and the-common oats 40. My neishbors all want them for seed. The threshermen and my grain dealers advise me not to sell them on the market at all, but to save them for this community. Thsy all think they are fine. I am well satisfied with my investment."-A. M. Morrison, Collin County, Texas.

\section{After 10 Years Says "Best Oats fo“r Texas." Dr. J. D. Lovelace, cf acre where others made 13."-J. L, Wil- liams, Azle, Texas.} McLennan County, Texas, was a purchaser of the first lot of FER UUSON NU. 71 OATS. He is a larje farmer. Here is his letter: "From several years experience and observation with FERGUSUN Nú. 71 OATs, grown on my own farm and my neishbors' farms, of cen right sideby-side with the common oats. I know that the FERGUSON NO. 71 OATS have yieided from 25 to 103 per cent more. The quality is better, they suffer less frum rust, stool more freely and stand th $=$ winter better. I find that it pays to secure freshly tested and improved seeds from season to season."

\section{Stond Drouth and Winter in Frio Connty.} "Renlying to your letter relative to oats bou ht of you last fall, will say that the oats had one rain in October, just after planting time, one rain, of about 1 inch, in January and nothing again until April 15th. I had grazed them all the time and after the April rain they ran up about 12 inches and made good grain, but was too short to cut so I just grazed them off. No oats stood up against the drouth like these oats did." -M. W. Lindholm, Frio County, Texas.

\section{“The Best Oats I Exer Planted."}

"FERGUSON NO. 71 OAT is the best I ever planted. Planted 10 acres with 15 bushels; got a good stand, stooled freely, went thruugh the winter fine, made a better yield and better quality than the common red oat."-Otis Wardlow, R. 1, MicCaskier, Ark.

\section{The Best Oats In the Community.}

"Sowed $1 \frac{1}{2}$ bushels per acre and made the best oats in the community. The yield was $1 / 3$ better. They are the best oats I have ever planted. "-M. L. Pierce, Millsap, Texas.

Can Sell AlI His Crop for Seed. "I will write you in regard to the No, 71 Uats I got from you last year. They out-yielded the common oats from 15 to 20 bushels per acre. I sowed them after the freeze in January and we had a dry Februsry so they were cut short. The grain was fine, the hədds were short and didn't multiply much on account of so much dry weather. Am well pleased with them and can sell all I have to spare for seed."-Tom Landrum, Coleman County, Texas.

\section{Gained 28 Bnshels on Oats; I2 Bushels} on Wheat. "FERGUSON NO. 71 SEED OATS made 63 bushels per acre where 0 thers mads 44, an 1 F $2 R$ RUUSON FULCASTER WHEAT made 21 bushels per

OkIahoma for Ferguson No. 71 Oats, "I like your FERGUSON NO. 71 OATS. I got some seod frum a neighbor, who got his seed troni you. 'I he FERuUsun Nu. 71 OATS made $1 / 3$ more per acre $t h \Rightarrow$ second year than the common red oats. They will grow un strunger land without falling than the $r \in d$ oxts"-A. A. Haning, Seminole County, Oklahoma.

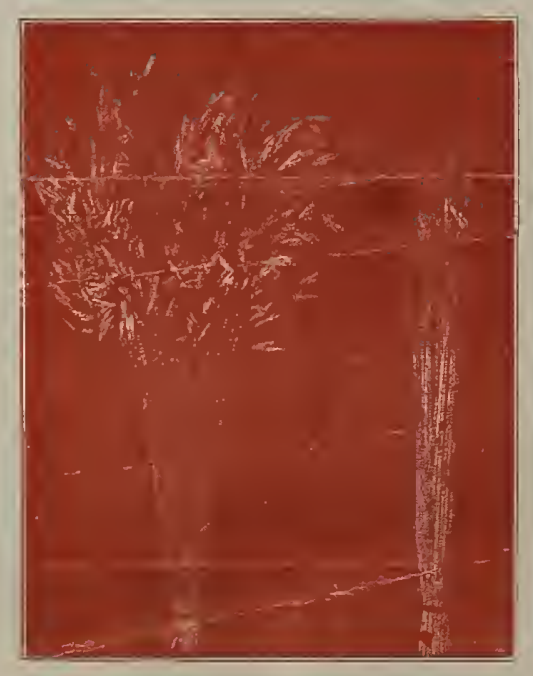

Smutted Stools Are Worse Than Weeds In Your Grain. We Supply Treated, Smut-Free Seeds.
Made S350 More With Ferguson No. 71 Oats. "I bought 70 bushels, planted 50 acres and made 10 bushels more per acre; I consider that I am ahead $\$ 350$. They stooled freely; much more so than the common red oats. The quality was the finest I ever threshed." -John Martin, R. 2, Burleson, Texas.

Made 1-3 More With Ferguson No, 7I Oats,

"They are the best oats I- ever saw. They stooled freely and made. $1 / 3$ more per acre. Nubody will make a mistake by planting FERGUSON NO. 71 OATS." -Marcus Gough, Roxton, Texas, R. 1.

Was Betier Than Native Oats, "In ans" wer to your question about your Nr. 71 Oats, will say that I didn't thresh the oats, but cuuld see that the oats from your seed were much better than the uther seed. Just how much I can't say. I wish that I had threshed them su that I would have seed fur another year." $-\Gamma$. J. Burks, Falls County, Texas.

Made \$18.70 An Acre W ith Feróuson No. 71 Oats. "I sowed 10 acres with 23 bushels of FERGUSON NO. 71 OATS. They made 20 bushels more than common red oats under the same cunditions. I was offered $72 \mathrm{c}$ ner bushel, making a differerce of $\$ 18.70$ an acre in the value of the two crups. They stooled more freely and made a better quality of oat. I never will sow anything else."-A.D. Ryan, Harmon Crunty, Oklahonia.

Low, Stont Stalk a n d Heavy Grain, "FERGUSON NO. 71 OATS made good after all. I sowed the oats the misdle of January. Had no rain 't.ll end of Annil. The oats were not tall, but were heavy from seed and straw according to other kinds. I am more than pleased with same. I am willing to order adain." -Otto W. Borchers, Guadalupe Cuunty, Texas.

Ontyielded Common Oats 21 Bushels. "I have just threshed the FERGUSON NO. 71 UATS. They threshed 50 bushels to the acre. My other oats threshed 35 bushels per acre. I sowed in Uctober. They fruze out fully half. 50 per cent of the fall sowing froze out completely in this county. I think I shall order some mure this fall. Will prefer spring planting. I also $w_{-}$nt some wheat. Of course $\mathrm{l}$ am very much pleased with my 0 ats. If the winter had not been so bad they would have made a third more. I expect to make an order in September." -J. M. McPherson, Hamilton Co. Texas 